Wage Differenti al s among Owner shi p Groups and Wbrker Qual i ty i n Vi et namese Manuf act ur i ng

\begin{tabular}{|l|l|}
\hline 著者 (英) & Er i c D. Ranst et ter, Ki en Tr ung Nguyen \\
\hline $\begin{array}{l}\text { j our nal or } \\
\text { publ i cat i on ti tl e }\end{array}$ & AG Wbrki ng Papers Ser i es \\
\hline vol une & $2015-05$ \\
\hline page r ange & $1-37$ \\
\hline year & $2015-03$ \\
\hline URL & ht t p: //i d. ni i . ac.j p/1270/00000037/ \\
\hline
\end{tabular}




\title{
Wage Differentials among Ownership Groups and Worker Quality in Vietnamese Manufacturing
}

\author{
Kien Trung Nguyen \\ The University of Danang, School of Economics, Vietnam \\ and \\ Eric D. Ramstetter \\ Asian Growth Research Institute and Kyushu University, Japan
}

Working Paper Series Vol. 2015-05

March 2015

The views expressed in this publication are those of the author(s) and do not necessarily reflect those of the Institute.

No part of this article may be used reproduced in any manner whatsoever without written permission except in the case of brief quotations embodied in articles and reviews. For information, please write to the Institute. 


\title{
Wage Differentials among Ownership Groups and Worker Quality in Vietnamese Manufacturing
}

\author{
Kien Trung Nguyen*, The University of Danang, School of Economics \\ and
}

Eric D. Ramstetter, Asian Growth Research Institute and Kyushu University

\begin{abstract}
This paper examines wage differentials among medium-large (20 or more employees) whollyforeign multinational enterprises (WFs), joint-venture multinationals (JVs), state-owned enterprises (SOEs), and domestic private firms in Vietnamese manufacturing. The analysis focuses on 2009 because it is possible to examine wage differentials after accounting for the influences of two measures of worker quality, educational background and occupation. Simple comparisons in large samples of 11 industries combined indicate that averages wages in JVs were about 92 percent higher than in private firms in 2009, SOEs and WFs paid 57 and 54 percent more than private firms, respectively. Corresponding, conditional differentials that control for the influences of worker education and occupation, as well as capital intensity, size, and shares of female workers, were substantially smaller, but positive and significant in large samples. Wage levels and differentials varied substantially among industries. Conditional differentials remained positive and significant for WFs and JFs in most of the 11 industries examined, but estimates of SOE-private differentials were insignificant in most industries. Robustness checks using 2007 data could not account for worker occupation, but revealed results similar to those for 2009.
\end{abstract}

JEL Classification Codes: F23, J31, L60, O53

Keywords: Multinational enterprises, manufacturing, wage differentials, state-owned enterprises, ownership

Acknowledgement: This paper is one output of the research project "Multinationals, Wages, and Human Resources in Asia's Large Developing Economies", which was funded by the Asian Growth Research Institute (formerly the International Centre for the Study of East Asian Development) in fiscal 2014 (ending March 2015). We thank AGI and the University of Danang, School of Economics for financial and logistic assistance. Valuable comments were also received at an AGI Seminar on 25 February 2015. Responsibility for all opinions expressed and any remaining errors or omissions are the authors' alone.

*Corresponding author, kien.nt@due.edu.vn 


\section{Introduction}

There is a growing literature indicating that foreign-owned multinational enterprises (MNEs) normally pay higher wages than domestic firms in host, developing economies. The most sophisticated studies to date have analysed manufacturing plants in Indonesia and Malaysia, and accounted for the fact that multinational enterprises tend to hire relatively welleducated workers and be relatively large and capital or input intensive compared to local plants (Lipsey and Sjöholm 2004; Ramstetter 2014; Ramstetter and Narjoko 2013). These studies often found positive and significant wage differentials between foreign MNEs and local plants, even after controlling the influences of worker education and sex, as well as plant size and capital intensity. However, aside from limited evidence in Ramstetter and Phan (2007), Tran (2007), and Fukase (2014a, 2014b), there is very little evidence regarding wage differentials among firm ownership groups in Vietnam, which accounts for the influence of worker quality. This paper partially fills the gap in the literature by using data on worker quality that were unavailable in previous years to analyse determinants of wages in manufacturing firms in Vietnam’s in 2007 and 2009,.

The relatively large role played by MNEs in Vietnam and Vietnam's intensified emphasis on outward-oriented economic liberalization since the early 2000s has generated interest how MNEs affect the local economy and local workers. State-owned enterprises (SOEs) have traditionally been designated to control key capital-intensive industries. However, the promulgation of the Enterprise Law in 2000, the negotiation of the Bilateral Trade Agreement with the United States in 2001, the implementation of many commitments made under the ASEAN (Association of Southeast Asian Nations) Free Trade Area (AFTA) by 2005 or shortly thereafter, and the implementation of further revisions to the Enterprise Law and related Investment Laws that eventually led to WTO (World Trade Organization) accession in 2006 were all substantive policy changes that reduced ownership-related policy biases in 
Vietnamese manufacturing. Correspondingly, the economic environment during 2007-09, was substantially more open and competitive than even five years previous, and many firms were still in the process of adjusting to the large policy changes. During this period, firms were also affected by the world financial crisis, which was partially responsible for the decline of Vietnam's economic growth rate to 5.4-6.4 percent in $2008-13$ from the $6.8-7.8$ percent that were experienced in 2000-07 (Asian Development Bank 2014).

In this paper, we first review the literature on MNE-local wage differentials (Section 2) and describe the enterprise data that are used for the analysis, focusing on unconditional differentials in wages and worker skills between MNEs and private firms (Section 3). Then we test if wage differentials are statistically significant after accounting for firm size, capital intensity, worker sex, and worker education in both 2007and 2009 (Section 4). For 2009, it is also possible to control for the influence of worker occupation. The focus is on analysis of 2009 data because they allow better control for worker quality, but the estimates for 2007 provide an important robustness check. Finally, Section 5 offers some conclusions and suggestions for future research.

\section{Literature review and Methodology}

There is a compelling theoretical rationale suggesting that MNEs will often pay higher wages than corresponding domestic enterprises in host developing economies. On the demand side, MNEs are often argued to possess large amounts of knowledge-based, generally intangible assets such as production technology, marketing networks and management systems. Possession of these firm-specific assets suggests that MNEs will be likely to be more efficient than non-MNEs, which is reflected by larger firm size, higher factor productivity, and/or correspondingly higher factor rewards. 
Many MNEs also require their employees, even relatively unskilled staff, to have engineering, marketing, and foreign language skills required to work with particular machinery and clients. In addition, many of these employees need to learn modern work disciplines, such as punctuality, tidiness and promptness, which may not be valued as highly in local firms, for example. Firms operating in developing economies like Vietnam often face shortages of skilled workers who have both engineering, foreign language, and modern management skills. Thus, MNEs relative unfamiliarity with local labor markets may make it more difficult for them to hire new skilled workers, or retain current skilled workers than domestic firms. This may motivate MNEs to pay relatively high wages as an incentive to increase the attractiveness of their firms to skilled workers or to reduce turnover.

On the supply side, workers may prefer to work for locally owned firms because they are more familiar with local management practices. In Vietnam, for example, it is clear that labor market practices often vary greatly between MNEs and local firms. Nonetheless, our impression is that most Vietnamese workers are not very opposed to working for MNEs and many might actually prefer MNE employment to the alternatives. This is supported by studies which suggest that internal migrants in Vietnam often prefer to work for MNEs over local firms (Fukase 2014b).

Some of the most comprehensive analyses of wage differentials to date have examined Indonesian manufacturing plants in 1996 and 2006 (Lipsey and Sjöholm 2004; Ramstetter and Narjoko 2013). For 1996, estimates of Mincer-type wage equations at the plant level found strong evidence that MNEs paid higher wages than domestic firms after controlling for size, input intensity, the share of female workers, and worker education. For 2006, estimates in large samples of all manufacturing plants combined and a few individual industries also reveal positive and significant wage differentials, but many of the industry-level regressions 
indicate that conditional wage differentials were not significant in the latter year. ${ }^{1}$ In addition, analyses of Malaysian plants in 2000-2004 also suggest that conditional wage differentials accounting for both worker education and occupation were positive and significant in most of the individual industries examined and when all sample industries were combined (Ramstetter 2014). Although they do not control for the effects of worker education or occupation, other studies of Malaysia (Lim 1977) and Thailand (Matsuoka-Movshuk and Movshuk 2006; Ramstetter 2004) also found positive and significant wage differentials after controlling for plant-level differences in capital intensity and size, for example.

Similar studies of Vietnam are sparse. Most of previous studies of wage differentials primarily focused on gender wage gaps, finding that women tend to earn significantly less than men (Liu 2001, 2004; McCarty 1999; Pham and Reilly 2007). Similar to this study, Ramstetter and Phan (2007) and Tran (2007), examined conditional wage differentials between MNEs and local firms in Vietnamese manufacturing during 2000-2005. Both studies found positive and significant wage differentials, but their measures worker quality (the shares of science and technical workers) were not as comprehensive as in the Indonesian or Malaysian data. More recently, the 2007 and 2009 enterprise surveys included more detailed questions on worker education, and the 2009 survey also has information on worker occupation. This study thus focuses on analyzing these years. A recent study by Fukase (2014a) used household data to compare the wages paid to workers in MNEs and domestic firms, also finding that MNEs and SOEs tended to pay higher wages than private firms and another study (Fukase 2014b) found that internal migrants were attracted by job opportunities in MNEs and SOEs.

\footnotetext{
${ }^{1}$ In the combined sample of all manufacturing plants, intercept dummies are used to capture industryspecific effects. The industry-level regressions are more general in that they allow intercepts and all slope coefficients to differ among industries
} 
In Vietnam, ownership-related wage differentials are also related to government regulations, which require MNEs to pay higher minimum wages than private companies (Nguyen 2014). For example, in 2006-2007 minimum wages in WFs and JVs were 58-93 percent higher than in domestic firms (private firms and SOEs combined), depending on the region. In 2009, these differentials declined to 38-50 percent. Foreign-domestic differentials in minimum wages were largest in Hanoi and Ho Chi Minh City and smallest in rural areas. On the other hand, it is important to note that minimum wage requirements only affect base salaries, and domestic firms often pay much higher bonuses than multinationals. ${ }^{2}$ As explained by Ramstetter and Phan (2007), SOEs were also required to pay relatively high minimum wages in previous years, though we have no new information on this point.

\section{The data, wage differentials and worker quality}

This study analyzes medium-large firms (20 or more employees) included in Vietnam's Annual Enterprise Surveys for 2007 and 2009 (General Statistical Office 2011, 2013). To date, only these two surveys have collected comprehensive information on employee education and wages. The 2009 data also have information on worker occupation but this indicator is not available for the 2007. All values are expressed in 2000 prices using appropriate deflators. ${ }^{3}$ Wages are defined to include regular salaries and other compensation such as bonuses, subsidies, social security, health insurance, and pension insurance. Real wages are calculated using the consumer price index (CPI).

\footnotetext{
2 See Appendix Table 7 and Asian Development Bank Institute newsletter of 23 October 2013; received by email on that date.

${ }^{3}$ Output is converted using a manufacturing output deflator at the two-digit level of Vietnam's Standard Industrial Classification. Capital is converted using the deflator is for fixed-capital formation from the national accounts (General Statistics Office various years a, various years b).
} 
Most MNEs, including both WFs and JVs, and SOEs are medium- or large-sized firms, which differ in many respects from smaller firms, which are predominantly private. Therefore, it is more meaningful to compare wages among medium-large manufacturing firms with a workforce of at least 20 employees. In addition to making the comparison more consistent and meaningful, excluding small firms also allows us to remove most outliers and most firms reporting implausible data. ${ }^{4}$ The analysis also excludes five industries with very few MNEs and/or SOEs (tobacco; publishing and printing; petroleum and gas; miscellaneous manufacturing; and recycling).

After eliminating firms that were small, had implausible data, or were in one of the five excluded industries, 10,221 sample firms remained in 2007 and 10,698 in 2009. These sample firms employed 2.79 million paid workers in 2007 and 3.12 million in 2009 (Table 1). These totals were 74 and 76 percent, respectively, of total employment reported for manufacturing firms in enterprise survey publications (General Statistics Office (2011, 2013) but only 48-49 percent of all manufacturing employees reported by the labor force surveys. In other words, although firms excluded from the samples were relatively small employers, there were a large number of manufacturing workers in units not surveyed by the enterprise surveys. Most were probably employed by household firms, which are excluded from the enterprise surveys.

As mentioned above, the Enterprise Law was promulgated in 2000 and revised as part of the WTO accession process in 2005-2006, along with SOE and foreign investment laws. Thus, by 2007-2009, there was a consistent legal framework and common investment climate for all types of firms. However, Vietnam’s foreign investment law has been relatively open since it’s promulgation in 1987 and Vietnam's policy implementation still favors both MNEs and SOEs

\footnotetext{
${ }^{4}$ In addition, only limited information is collected from very small local firms with 10 or fewer employees (Jammal et al., 2006).
} 
over private firms in many cases. Partially as a result of this legacy, MNEs and SOEs accounted for relatively large shares of paid employment in manufacturing firms (Table 1).

However, reflecting efforts to privatize and equitize many SOEs, SOE shares declined markedly after 2000, while MNE shares increased. Table 1 indicates these trends continued in 2007-09, with SOE shares of paid workers in the 11 sample industries declining from 13 to 10 percent while the total MNE (JV+WF) share rose from 43 to 47 percent. WFs accounted for the vast majority of MNE employment, their share rising from 37 to 42 percent while the JV share fell slightly from 5.3 to 4.6 percent. WFs are concentrated in labor-intensive industries such as wood and furniture, apparel, leather, and footwear; and electronics. WF employment shares also exceeded one quarter in three relatively capital-intensive industries: transportation machinery, textiles, and basic metals and metal products.

Of the 11 sample industries, paid employment was largest in apparel leather, and footwear, with 1.08 million paid workers in 2007 and 1.21 million in 2009, followed by food and beverages with 0.35 and 0.40 million, respectively, and wood and furniture, with 0.30 and 0.31 million, respectively. 54 and 60 percent, respectively of the paid workers in the apparel group worked in WFs WFs were also large in the smaller electronic machinery industry, accounting for 72 and 80 percent, respectively, and the paid workers in this industry. These two industries accounted for two-thirds of the paid workers in WFs. At the other end of the scale, WF shares were relatively small in food and beverages (13 percent) and non-metallic mineral products (6.1-6.4 percent). JV shares were almost one-fifth in transportation machinery, but much smaller (6.4 percent or less) in the 10 other sample industries. In 2007, SOE shares were one fifth or more in textiles, chemicals, rubber, and plastics, non-metallic mineral products, and transportation machinery, but in 2009 this was only true in transportation machinery. 
Table 2 presents unconditional wage differentials between WFs, JVs, and SOEs on the one hand, and domestic private firms on the other, for 2007 and 2009. On average, JVs paid the highest wages; the mean JV-private wage differential was 175 percent in 2007 and 92 percent in 2009 when firms in all 11 industries were combined. For WFs and SOEs, mean differentials were 68 and 72 percent, respectively, in 2007, and 54 and 57 percent, respectively, in 2009. In other words, on average, JVs paid the highest mean wages in the 11 sample industries, followed distantly by SOEs, and WFs, but all groups paid substantially higher wages than private firms. JVs also paid the highest wages in all 11 industries in 2007 and in eight industries in 2009. In 2009, WFs paid the highest wages in the apparel group and WFs and SOEs both paid the most in paper and general machinery. Although WF-private differentials in were the smallest in samples of all 11 industries combined, WF-private differentials were the smallest in five industries in 2007 and three in 2009. On the other hand, SOE-private differentials were the smallest in six industries in both 2007 and 2009.

Previous, plant-level evidence for Indonesia (Ramstetter and Narjoko 2013, Table 2) suggests a similar tendency for MNEs with large ownership shares (90 percent or larger) to have relatively small unconditional wage differentials compared to other MNEs. MNE-related wage differentials in Table 1 are also of similar as those for Indonesian production workers in 2006, though they are considerably smaller than differentials for 1996 and for non-production workers in 2006. This pattern makes sense because most of the paid workers in the Vietnamese samples are production workers or non-production workers in relatively lowwage occupations.

The size of MNE-local wage differentials may also be related to the size of the technology gap between MNEs and private plants, which is likely to be smaller at higher levels of wages and incomes. There is also a similar, though less consistent tendency for WFs or MNEs with relatively large ownership shares to have relatively small labor productivity differentials 
relative to local plants among ownership groups in Indonesia, Thailand, and Vietnam (Ramstetter 2004; Ramstetter and Phan 2013; Takii 2004; Takii and Ramstetter 2005). Another factor leading to wage differentials is the previously noted tendency Vietnam's minimum, base wages to be highest in MNEs, though this difference is often offset by higher payments of other compensation in domestic firms and minimum wage requirements are probably not binding for many MNEs.

When the 11 sample industries are combined, shares of paid workers who completed tertiary education were also higher in SOEs and JVs than in WFs and private firms in both years (Table 3). In JVs this share increased from 16 percent in 2007 to 17 percent in 2009, in SOEs the share increased from 13 to 17 percent, respectively. Corresponding shares in WFs and private firms also increased but were much smaller (5.9-7.3 percent). Although it is reasonable to expect tertiary shares to rise during this period, the large increase for SOEs suggests substantial differences in the SOE sample between the two years, perhaps reflecting the influence of privatization.

There is also large variation in tertiary shares among industries (Table 3). For example, all ownership groups had relatively high tertiary shares in the chemicals group and electronic machinery, but relatively low shares in the apparel group. On the other hand, WFs and SOEs had relatively high tertiary shares in food and beverages, as did JVs in 2009, but tertiary shares were relatively low in private firms in both years. At the industry level, there are a number of other large changes in tertiary shares between 2007 and 2009 which suggest substantial differences in underlying sample firms in some industry-owner combinations. ${ }^{5}$

\footnotetext{
${ }^{5}$ For example, tertiary shares increased or decreased by more than 6 percentage points for SOEs and JVs in the metals group, general machinery, and electronic machinery, JVs only in wood and furniture, and SOEs only in transportation machinery. Although these large changes are not impossible and there were large economic changes in 2007-09, variables like shares of workers by educational background don't usually change much in a short period of time.
} 
Mean shares of moderately educated workers (those who completed secondary education (e.g., high school or vocational training college, but not tertiary education) in all sample firms were larger than corresponding tertiary shares all ownership groups in 2007 and for private firms and WFs, but not for SOEs or JVs in 2009 (Tables 3, 4). Moreover, differences between secondary shares and tertiary shares tended to be relatively small, six percentage points or less in absolute value. This pattern contrasts sharply with Indonesia in 2006, for example, where secondary shares tended to be substantially larger (e.g., 10-20 percentage points or even more) than tertiary shares. The contrast partially reflects the relatively heavy emphasis Vietnam has placed on higher education at relatively low levels of per capita income.

In addition to data on worker education, the 2009 survey also provides data on four types of worker occupations, two of which are highly paid, managerial employees, and professional, technical and supervisory employees. To further account for worker quality in this year, shares of these highly paid workers are also calculated (Table 5). In all 11 sample industries combined, SOEs and JVs also had the highest shares of high quality workers by this measure 24 and 22 percent, respectively, but in WFs and private firms, these shares were only 16 percent. Similar to tertiary shares, shares of highly paid workers were relatively large for all groups in the chemicals group and electronic machinery, in addition to the metals group, general machinery, and transportation machinery..

\section{Conditional wage differentials from econometric approach}

As emphasized in the literature, ownership-related wage differentials in the manufacturing sector are likely to be related to workforce characteristics such as education attainment and occupation. The literature also suggests that firm characteristics such as size, capital intensity, and the share of females in paid employees may also influence the extent of wage differentials. Therefore, in this section we continue with an econometric analysis to examine the extent to 
which ownership-related wage differentials persist after controlling for the influences of worker education, occupation, and sex, as well as firm capital intensity and size. Similar to previous studies, we estimate the following model:

$$
\begin{aligned}
\ln \left(R W_{i j}\right) & =a_{0}+a_{1} \ln \left(K I_{i j}\right)+a_{2} \ln \left(R O_{i j}\right)+a_{3} S H_{i j}+a_{4} S M_{i j}+a_{5} S P_{i j} \\
& +a_{6} S F_{i j}+a_{7} D W_{i j}+a_{8} D J_{i j}+a_{9} D S_{i j}+\varepsilon_{i j}
\end{aligned}
$$

where

$R W_{i j}=\quad$ Average real wage of firm $i$ of industry $j$.

$R O_{i j}=\quad$ Real output of firm $i$ of industry $j$.

$K I_{i j}=\quad$ Capital intensity of firm $i$ of industry $j$, measured as the ratio of fixed capital stock over employment after deflating capital stock at a constant value.

$S H_{i j}=\quad$ A share of highly educated employees in total employment of firm $i$ of industry $j$ (per cent).

$S M_{i j}=\quad$ A share of moderately educated employees in total employment of firm $i$ of industry $j$ (per cent).

$S P_{i j}=\quad$ A share of employees in highly paid occupation in total employment of firm $i$ of industry $j$ (per cent).

$S F_{i j}=\quad$ A share of female employees in total employment of firm $i$ of industry $j$ (per cent).

$D W_{i j}=\quad$ A dummy for wholly-owned, foreign-invested enterprises (wholly foreign firms - WF), taking a value of one if a firm is wholly owned FIE and zero otherwise.

$D J_{i j}=\quad$ A dummy for joint venture enterprises (JV), taking a value of one if a firm is FIE joint venture and zero otherwise.

$D S_{i j}=\quad$ A dummy for state-owned enterprises (SOE), taking a value of one if a firm is state-owned and zero otherwise.

$\varepsilon_{i j}=\quad$ A stochastic error term.

All estimates also include vectors of dummy variables identifying six regions and as many as 29 industries, usually defined at the two- or three-digit level of Vietnam's Standard Industrial Classification (VSIC) to account for region-specific and industry-specific influences on the 
constant which are not captured by the firm-level variables. ${ }^{6}$ Industry-specific effects on constants and slopes are also accounted for in more detail by estimating equations for each of the 11 sample industries separately, as well as all 11 industries combined.

Coefficients on capital intensity $\left(a_{1}\right)$ and real output $\left(a_{2}\right)$ are expected to be positive because capital-intensive and large firms generally pay higher wages than labor-intensive or small firms. Coefficients on the shares of highly or moderately educated workers $\left(a_{3}, a_{4}\right)$ and shares of highly paid workers occupations $\left(a_{5}\right)$ should also be positive because they suggest higher worker quality in firms with relatively high shares. In contrast, the coefficient on the share of female workers $\left(a_{6}\right)$ is likely to be negative because firms with a higher proportion of female workers tend to have lower average wages. ${ }^{7}$ Finally, if wage differentials between WFs JVs, and SOEs, on the one hand, and private firms, on the other, persist after controlling for worker education, occupation, and sex, as well as firm size and capital intensity, the signs of the coefficients on DW, DJ, and DS ( $\left.a_{7}, a_{8}, a_{9}\right)$ will be positive.

Because data on worker occupation are only available for 2009, we focus on estimates for this year, but also provide estimates for 2007 without this variable as a robustness check. Estimates are performed in cross sections, which mean that the coefficients on DW, DJ, and DS $\left(a_{7}, a_{8}, a_{9}\right)$ can be interpreted as conditional wage differentials similar to the unconditional differentials in Table 2. However, it is also possible that wages could influence firm's capital intensity and size, creating potential simultaneity between the dependent and independent variables. To check for the robustness of the results to simultaneity concerns, estimates of both contemporaneous and lagged specifications, where capital intensity and output are

\footnotetext{
6 The regions are the Hanoi, the Red River Delta, the North Mountainous Area, the Central Coast and Central Highland Area, the Southeast Area, Ho Chi Minh City and the Mekong Delta. Industries are defined to have at least two of each of the four ownership types.

${ }^{7}$ Females tend to earn less than males because they tend to be less educated and have less experience in high paying jobs, and because they are discriminated against in the workplace and when educational resources are allocated.
} 
lagged one year, are compared. All estimates use robust standard errors to account for heteroskedasiticity that can be expected when firm-level, scale variables (e.g., output, capital intensity) are used.

In large samples of firms in all 11 industries combined, estimated coefficients were always consistent with expectations for 2007 and generally consistent for 2009 (Table 6). In both years, coefficients on firm size, shares of highly educated workers, and female shares had the expected sign and were highly significant at the 1 percent level or better. Similarly, coefficients on capital intensity and the share of moderately educated workers were positive and highly significant for 2007. For 2009, the coefficient on the share of highly paid workers was also positive and highly significant, and the coefficient on the share of moderately educated workers was also significant at the standard 5 percent level. However, the coefficient on capital intensity was insignificant in 2009. Nonetheless, the goodness of fit measure $\left(R^{2}\right)$ was about 0.48 for 2009 estimates and 0.42 for 2007, suggesting that the model explained the variation in the dependent variable rather well, given the cross sectional context. Moreover, the differences between the size of most coefficients, notable the coefficients on the ownership dummies, were similar in the contemporaneous and lagged specifications, suggesting that any simultaneity bias is likely to be small.

Most importantly, the estimates suggest that MNEs and SOEs paid significantly higher wages than local firms, even after controlling for the influences of capital intensity, firm size as well as worker education, sex, and occupation. However, conditional wage differentials were all substantially smaller than corresponding unconditional differentials in Table 2. For example, conditional WF-private wage differentials were about 28-29 percent in 2009 and 2325 percent in 2007, JV-private differentials were 28-30 percent and 29-31 percent, respectively, and SOE-private differentials were 9-10 percent and 13-15 percent, respectively, 
and that all of these wage differentials were highly significant statistically. ${ }^{8}$ These results are consistent with the patterns observed in Table 2 because they imply JVs pay the highest wages, followed by WFs, SOEs and lastly private firms. On the other hand, the conditional differentials were much closer in magnitude than unconditional differentials for WFs and JVs; in other words, the controls in equation (1) apparently explain a much larger portion of JVprivate wage differentials than of WF-private differentials. Nonetheless, Wald tests suggest it is statistically meaningful to distinguish JVs and WFs when estimating equation (1).

Given substantial differences in the cross sections used, the lack of worker occupation data for 2007, and that fact that the capital intensity variable was insignificant for 2009, it is difficult to compare differentials between 2007 and 2009 meaningfully. Comparisons between the two years are further confounded by large differences in the macroeconomic environment in these two years. For example, the growth rate of real manufacturing GDP plummeted from over 12.4 percent in 2007 to 9.8 percent in 2008 and only 2.8 percent in 2009 , while the growth of the manufacturing deflator skyrocketed from 4.5 percent in 2007 to 13.2 percent in 2008 and 7.3 percent in $2009 .{ }^{9}$ On the other hand, the finding of significant, ownershiprelated wage differentials in both years suggests they were an important feature of Vietnamese manufacturing which were robust to substantial macroeconomic change.

Estimates of equation (1) also performed relatively well when estimates separately in the 11 sample industries. For example, the goodness of fit measure always exceeded 0.4 in six of the 11 industries and was below 0.3 in only one industry (the apparel group) in 2007. Coefficients on real output, the share of highly educated workers were positive and significant at standard levels in almost all estimates. Coefficients on the share of female workers were negative and significant in 19 of the 22 estimates for 2009, but only 14 for 2007. The coefficient on the

\footnotetext{
8 Because dependent and independent variables are in natural logs, conditional differentials are calculated as the exponential value of the relevant coefficients $\left(a_{7}, a_{8}, a_{9}\right)$ from estimates of equation (1).

${ }^{9}$ Data downloaded from www.gso.gov.vn on 22 January 2014.
} 
share of highly paid workers was also significant in 14 of the 22 cases for 2009. On the other hand, coefficients on capital intensity and the share of moderately educated workers were almost never significant at the industry level.

As with unconditional wage differentials, conditional wage differentials between WFs, JVs, and SOEs, on the one hand, and domestic private firms on the other, varied greatly among industries (Table 7). ${ }^{10}$ WF-private differentials were positive and significant in all 11 industries in 2009 and 10 of 11 industries (all except non-metallic mineral products) in 2007. WF-private differentials tended to be largest in general machinery (55-59 percent in 2009 and 40-42 percent in 2007), the metals group (34 and 31-32 percent, respectively), transportation machinery (32-35 and 62-65 percent, respectively), the chemicals group (35 and 36-38 percent, respectively), and textiles (38-40 and 28-29 percent, respectively). On the other hand, WF-private differentials were consistently small in the apparel group (21 and 10-11 percent, respectively).

Conditional, JV-private wage differentials were also positive in 10 of the 11 industry groups (all except paper) in 2009 (Table 7). However, in 2007 differentials were insignificant at standard levels in four industries: the apparel group, wood and furniture, paper, and general machinery. The JV-private differential was also rather small in the apparel group in 2009, though it was positive and highly significant. JV-private differentials were significant and tended to be largest in both years in the chemicals group, electronic machinery, and the metals group in both years. Estimated differentials were also relatively large in textiles in 2009, but smaller in 2007, while the reverse was true in transportation machinery. Wald tests again indicate that it is usually meaningful to distinguish JVs and WFs when estimates of equation (1) are performed at the industry level.

\footnotetext{
10 See Appendix Table 5 for all slope coefficients and equation information provided for the 11 industry sample in Table 6. To conserve space, Table 7 only provides wage differential coefficients and results of testing the null hypothesis that JV-private and WF-private differentials were equal.
} 
Although most WF-private and JV-private differentials were significant when estimated at the industry level, most SOE-private wage differentials were insignificant. There were three notable exceptions: food and beverages, the chemicals group, and electronic machinery. There was also some indication of positive and significant SOE-private differentials in transportation machinery in 2007 and in the apparel group in 2009 (lagged specification only). In other words, most of the unconditional, SOE-private differentials are apparently explained by differences in worker education, occupation, and sex, as well as firm-level capital intensity and size.

\section{Conclusions}

This paper has examined the extent of wage differentials among medium-large MNEs, SOEs, and domestic private firms in Vietnamese manufacturing in 2007 and 2009, following the numerous policy reforms that removed ownership-related biases and lowered protection from imports. When all sample firms were combined, simple comparisons suggest that average wages were 92-175 percent higher in joint venture MNEs than in private firms, while average wages in SOEs and wholly foreign MNEs were 54-72 percent higher than in private firms. Wage levels and unconditional wage differentials between JVs, WFs, and SOEs on the one hand, and private firms on the other, varied substantially among the 11 sample industries studied.

Conditional wage differentials which account the influences of worker education, occupation, and sex, in addition to firm capital intensity and size on wage determination at the firm level were positive and significant for WFs, JVs, and SOEs when estimated in large samples of including all 11 industries. However, conditional wage differentials were much smaller than corresponding, unconditional differentials, 28-31 percent for JVs, 23-29 percent for WFs, and 9-16 percent for SOEs. Moreover, when conditional differentials were estimated 
at the industry level, they were insignificant for SOEs in most industries. On the other hand, conditional differentials were significant in 10 of 11 industries for WFs in both years and for JVs in 2009, and in seven industries in 2007. The consistency of these results is important because 2007 and 2009 were two very different years and suggests findings of positive and significant JV-private and WF-private wage differentials is rather robust.

Because the industry-level results indicate substantial differences in slope coefficients among industries, industry-level estimates of wage differentials are probably more accurate than results from large samples of all 11 industries combined. These results also suggest that industry-level differentials were more persuasive in Vietnam in 2007 and 2009 than MNEprivate differentials in Indonesia in 1996 and 2006 and MNE-local differentials in Malaysia in 2000-2004. They are also consistent with results from studies of Vietnamese household data which suggest MNEs tend to pay relatively high wages and attract immigrants.

In short, these results provide important support for previous studies indicating that MNEs often pay significantly higher wages than local firms or plants in Southeast Asia, even after accounting important aspects of worker quality and other firm- or plant-level characteristics affecting wage determination. These results suggest there are important benefits accruing to workers in MNEs and conversely provide important evidence that MNEs do not exploit their workers unfairly. On the other hand, they should not be construed as evidence that workers would be better off if the government were to promote MNEs at the expense of other ownership groups, because MNE-local wage differentials are related to firm characteristics that distinguish MNEs from non-MNEs.

Although these results are important, further research in this area should seek to address a number of related issues. For example, how do changes in ownership affect wages and employment? Further investigation of this issue is particularly relevant in Vietnam because it can help illustrate the effects of privatizing SOEs. Another important question is how does 
MNE presence affect wage levels in domestic firms or are there wage spillovers from MNE presence? Analysis of issues raised these questions requires the use of panel data, the creation of which is not straightforward in the Vietnamese case.

\section{References}

Asian Development Bank 2014, Key Indicators for Asia and the Pacific 2014, 45th Edition. Manila: Asian Development Bank.

Fukase, E 2014a, 'Foreign Wage Premium, Gender and Education: Insights from Vietnam Household Surveys,' The World Economy, vol. 37, no. 6, pp. 834-55.

Fukase, E 2014b, 'Job Opportunities in Foreign Firms and Internal Migration in Vietnam', Asian Economic Journal, vol. 28, no. 3, pp. 279-99.

General Statistics Office 2011, Business Results of All Enterprises in Vietnam in 2009, Vol. 1 \& 2, Hanoi: Statistical Publishing House and underlying firm-level data for 2007-2009 supplied by the General Statistics Office.

General Statistics Office 2013, Development of Vietnam Enterprises in the Period of 20062011, Hanoi: Statistical Publishing House and underlying firm-level data for 2006-2009 supplied by the General Statistics Office.

General Statistics Office various years a, Statistical Yearbook, 2000-2004 issues, Hanoi: Statistical Publishing House.

General Statistics Office various years b, Statistical Yearbook of Vietnam, 2005-2013 issues, Hanoi: Statistical Publishing House.

Jammal, Y, Thang, DT and Thuy, PD 2006, "Vietnam Annual Enterprise Survey" Report of GSO/UNDP/DFID Project 00040722 "Support to Socio-Economic Development Monitoring", General Statistics Office, Hanoi.

Lim, D 1977, 'Do foreign companies pay higher wages than their local counterparts in Malaysian manufacturing?', Journal of Development Economics, vol. 4, no. 1, pp. 55-66.

Lipsey, RE and Sjöholm, F 2004, 'Foreign direct investment, education and wages in Indonesian manufacturing', Journal of Development Economics, vol. 73, no. 1, pp. 41522.

Liu, AY 2001, 'Markets, inequality and poverty in Vietnam', Asian Economic Journal, vol. 15, no. 2, pp. 217-35.

Liu, AY 2004, 'Gender wage gap in Vietnam: 1993 to 1998', Journal of Comparative Economics, vol. 32, no. 3, pp. 586-96. 
Matsuoka-Movshuk, A and Movshuk, O 2006, 'Multinational Corporations and Wages in Thai Manufacturing', in ED Ramstetter and F Sjöholm (eds), Multinational corporations in Indonesia and Thailand : wages, productivity and exports, Palgrave Macmillan, New York, pp. 54-81.

McCarty, A 1999, 'Vietnam's Labour Market in Transition', in Law and Labour Market Regulation in Asian: proceedings of the Law and Labour Market Regulation in Asian University of the Philippines.

Nguyen, KT 2014, 'Economic reforms, manufacturing employment and wages in Vietnam', PhD Dissertation thesis, Australian National University, Canberra.

Pham, T-H and Reilly, B 2007, 'The gender pay gap in Vietnam, 1993-2002: A quantile regression approach', Journal of Asian Economics, vol. 18, no. 5, pp. 775-808.

Ramstetter, ED 2004, 'Labor productivity, wages, nationality, and foreign ownership shares in Thai manufacturing, 1996-2000', Journal of Asian Economics, vol. 14, no. 6, pp. 861-84.

Ramstetter, ED 2014, 'Exporting, education, and wage differentials between foreign multinationals and local plants in Indonesia and Malaysian manufacturing', in $\mathrm{P}$ Athukorala, et al. (eds), Trade, Development and Political Economy in East Asia Essays in Honour of Hal Hill, Institute of Southeast Asian Studies (ISEAS) Publishing, Singapore, pp. 112-33.

Ramstetter, ED and Narjoko, D 2013, 'Wage Differentials between Foreign Multinationals and Local Plants and Worker Education in Indonesian Manufacturing', Working Paper 2013-23, Kitakyushu: International Centre for the Study of Development.

Ramstetter, ED and Phan, MN 2007, 'Employee Compensation, Ownership, and Producer Concentration in Vietnam's Manufacturing Industries', ICSEAD Working Paper 200707, Kitakyushu: International Centre for the Study of East Asian Development.

Ramstetter, ED and Phan, MN 2013, 'Productivity, ownership, and producer concentration in transition: Further evidence from Vietnamese manufacturing', Journal of Asian Economics, vol. 25, pp. 28-42.

Takii, S 2004, 'Productivity differentials between local and foreign plants in Indonesian manufacturing, 1995', World Development, vol. 32, no. 11, pp. 1957-69.

Takii, S and Ramstetter, ED 2005, 'Multinational presence and labour productivity differentials in Indonesian manufacturing, 1975-2001', Bulletin of Indonesian Economic Studies, vol. 41, no. 2, pp. 221-42.

Tran, TQ 2007, 'Foreign direct investment in industrial transition : a case study of Vietnam ', The Australian National University, Canberra, Australia. 
Table 1: Total paid employees in sample firms (number) and shares of SOEs, WFs, and JVs shares (\% of industry subtotals)

\begin{tabular}{|c|c|c|c|c|c|c|c|c|}
\hline \multirow[b]{2}{*}{ Industry } & \multicolumn{4}{|c|}{2007} & \multicolumn{4}{|c|}{2009} \\
\hline & $\begin{array}{l}\text { All firms, } \\
\text { number }\end{array}$ & $\begin{array}{r}\text { SOE } \\
\text { shares }\end{array}$ & $\begin{array}{r}\text { WF } \\
\text { shares }\end{array}$ & $\begin{array}{r}\text { JV } \\
\text { shares }\end{array}$ & $\begin{array}{l}\text { All firms, } \\
\text { number }\end{array}$ & $\begin{array}{r}\text { SOE } \\
\text { shares }\end{array}$ & $\begin{array}{r}\text { WF } \\
\text { shares }\end{array}$ & $\begin{array}{r}\text { JV } \\
\text { shares }\end{array}$ \\
\hline 11 sample industries & $2,793,123$ & 12.80 & 37.50 & 5.33 & $3,121,007$ & 9.93 & 42.30 & 4.59 \\
\hline Food \& beverages & 354,508 & 14.06 & 12.77 & 5.89 & 403,724 & 9.64 & 13.05 & 6.39 \\
\hline Textiles & 152,230 & 22.47 & 32.53 & 4.55 & 142,013 & 14.67 & 38.87 & 2.25 \\
\hline Apparel, leather, \& footwear & $1,081,636$ & 7.25 & 53.97 & 4.85 & $1,205,799$ & 4.89 & 60.22 & 3.71 \\
\hline Wood products \& furniture & 300,553 & 6.79 & 32.46 & 2.70 & 313,291 & 4.09 & 37.24 & 2.37 \\
\hline Paper & 57,452 & 15.73 & 19.99 & 0.81 & 62,779 & 12.73 & 24.16 & 0.68 \\
\hline Chemicals, rubber, \& plastics & 186,057 & 20.81 & 29.99 & 4.96 & 212,183 & 15.47 & 36.62 & 3.40 \\
\hline Non-metallic mineral products & 197,056 & 22.65 & 6.17 & 5.50 & 215,953 & 19.11 & 6.41 & 4.41 \\
\hline Basic metals \& metal products & 147,612 & 18.24 & 25.33 & 4.30 & 172,630 & 17.62 & 30.85 & 3.71 \\
\hline General machinery & 39,392 & 18.52 & 23.63 & 1.56 & 43,748 & 18.03 & 25.86 & 1.65 \\
\hline Electronic machinery & 155,360 & 7.48 & 71.74 & 6.31 & 193,414 & 5.09 & 79.65 & 4.78 \\
\hline Transportation machinery & 121,270 & 30.14 & 27.78 & 19.15 & 155,475 & 31.06 & 28.42 & 18.39 \\
\hline Excluded industries and firms & 490,934 & 22.13 & 36.94 & 0.98 & 523,856 & 12.37 & 36.00 & 1.28 \\
\hline
\end{tabular}

Note: Samples include firms with 20 or more paid workers and positive sales, worker compensation, and fixed assets; excluded industries are tobacco, publishing and printing, petroleum products, miscellaneous manufacturing, and recycling. Source: Author's compilations from General Statistics Office (2011, 2013). 
Table 2: Mean compensation per worker in private firms (million dong) and unconditional ownership-related wage differentials (percentage differentials) for paid workers in sample firms

\begin{tabular}{|c|c|c|c|c|c|c|c|c|}
\hline \multirow[b]{2}{*}{ Industry } & \multicolumn{4}{|c|}{2007} & \multicolumn{4}{|c|}{2009} \\
\hline & $\begin{array}{r}\text { Private } \\
\text { firms }\end{array}$ & $\begin{array}{r}\text { SOE- } \\
\text { private }\end{array}$ & $\begin{array}{r}\text { WF- } \\
\text { private }\end{array}$ & $\begin{array}{r}\text { JV- } \\
\text { private }\end{array}$ & $\begin{array}{r}\text { Private } \\
\text { firms }\end{array}$ & $\begin{array}{r}\text { SOE- } \\
\text { private }\end{array}$ & $\begin{array}{r}\text { WF- } \\
\text { private }\end{array}$ & $\begin{array}{r}\text { JV- } \\
\text { private }\end{array}$ \\
\hline 11 sample industries & 12.85 & 72 & 68 & 175 & 14.49 & 57 & 54 & 92 \\
\hline Food \& beverages & 11.63 & 92 & 59 & 167 & 14.90 & 54 & 83 & 88 \\
\hline Textiles & 11.28 & 36 & 62 & 77 & 11.71 & 40 & 62 & 84 \\
\hline Apparel, leather, \& footwear & 12.12 & 4 & 24 & 24 & 12.53 & 15 & 39 & 30 \\
\hline Wood products \& furniture & 11.54 & 28 & 40 & 67 & 11.72 & 18 & 53 & 67 \\
\hline Paper & 12.55 & 58 & 46 & 131 & 14.42 & 61 & 61 & -5 \\
\hline Chemicals, rubber, \& plastics & 14.68 & 123 & 134 & 230 & 17.13 & 82 & 66 & 86 \\
\hline Non-metallic mineral products & 12.03 & 71 & 42 & 231 & 14.10 & 78 & 67 & 107 \\
\hline Basic metals \& metal products & 14.66 & 54 & 62 & 155 & 16.53 & 36 & 45 & 92 \\
\hline General machinery & 16.31 & 33 & -1 & 79 & 18.30 & 32 & 31 & 28 \\
\hline Electronic machinery & 16.09 & 88 & 176 & 188 & 20.11 & 50 & 11 & 117 \\
\hline Transportation machinery & 14.63 & 73 & 5 & 168 & 17.63 & 18 & 24 & 72 \\
\hline
\end{tabular}

Note: See Table 1 for a precise definition of sample firms; compensation refer to all payments to workers, including employer contributions to social insurance.

Source: Author's compilations from General Statistics Office (2011, 2013). 
Table 3: Shares of paid workers with tertiary education in sample firms (percent)

\begin{tabular}{|c|c|c|c|c|c|c|c|c|}
\hline \multirow[b]{2}{*}{ Industry } & \multicolumn{4}{|c|}{2007} & \multicolumn{4}{|c|}{2009} \\
\hline & Private & SOEs & WFs & JVs & Private & SOES & WFs & JVs \\
\hline 11 sample industries & 5.93 & 12.57 & 6.80 & 15.55 & 6.71 & 17.49 & 7.30 & 16.90 \\
\hline Food \& beverages & 5.71 & 11.73 & 14.40 & 6.50 & 6.60 & 14.25 & 14.87 & 18.49 \\
\hline Textiles & 4.34 & 9.29 & 3.68 & 2.01 & 4.19 & 10.15 & 3.61 & 7.43 \\
\hline Apparel, leather, \& footwear & 3.22 & 3.32 & 2.08 & 7.98 & 3.51 & 5.87 & 2.33 & 2.64 \\
\hline Wood products \& furniture & 3.63 & 10.93 & 2.52 & 17.19 & 3.95 & 12.30 & 3.22 & 8.54 \\
\hline Paper & 5.63 & 9.88 & 6.65 & 18.49 & 6.20 & 9.65 & 6.24 & 16.84 \\
\hline Chemicals, rubber, \& plastics & 9.85 & 17.03 & 11.47 & 15.34 & 10.24 & 22.59 & 11.72 & 17.02 \\
\hline Non-metallic mineral products & 4.01 & 11.01 & 7.97 & 19.13 & 5.01 & 15.69 & 10.51 & 17.57 \\
\hline Basic metals \& metal products & 7.67 & 13.77 & 8.69 & 17.63 & 9.52 & 19.95 & 8.24 & 25.64 \\
\hline General machinery & 10.53 & 16.39 & 7.46 & 28.04 & 15.27 & 32.31 & 12.69 & 15.52 \\
\hline Electronic machinery & 13.21 & 21.00 & 9.11 & 13.83 & 17.13 & 31.07 & 9.31 & 32.80 \\
\hline Transportation machinery & 6.74 & 16.79 & 4.83 & 14.52 & 10.33 & 24.16 & 7.32 & 18.20 \\
\hline
\end{tabular}

Note: See Table 1 for a precise definition of sample firms; workers with tertiary education are those who successfully completed college, university, or graduate school.

Source: Author's compilations from General Statistics Office (2011, 2013). 
Table 4: Shares of paid workers with secondary education in sample firms (percent)

\begin{tabular}{|c|c|c|c|c|c|c|c|c|}
\hline \multirow[b]{2}{*}{ Industry } & \multicolumn{3}{|c|}{2007} & \multicolumn{5}{|c|}{2009} \\
\hline & Private & SOEs & WFs & JVs & Private & SOEs & WFs & $\mathrm{JVs}$ \\
\hline 11 sample industries & 12.11 & 12.77 & 11.21 & 16.19 & 11.54 & 15.08 & 10.77 & 15.98 \\
\hline Food \& beverages & 9.94 & 15.64 & 16.03 & 15.10 & 9.73 & 18.37 & 14.70 & 17.61 \\
\hline Textiles & 7.06 & 8.03 & 9.03 & 7.59 & 7.89 & 9.98 & 9.50 & 6.32 \\
\hline Apparel, leather, \& footwear & 7.15 & 5.40 & 4.72 & 7.19 & 6.39 & 6.26 & 5.24 & 4.81 \\
\hline Wood products \& furniture & 8.22 & 10.03 & 5.02 & 10.64 & 7.78 & 9.46 & 4.32 & 12.68 \\
\hline Paper & 12.00 & 10.86 & 11.06 & 21.21 & 10.65 & 11.22 & 9.93 & 27.78 \\
\hline Chemicals, rubber, \& plastics & 14.97 & 14.64 & 14.62 & 19.37 & 14.53 & 14.90 & 12.98 & 17.60 \\
\hline Non-metallic mineral products & 8.78 & 11.77 & 10.15 & 17.93 & 9.74 & 11.84 & 15.47 & 21.42 \\
\hline Basic metals \& metal products & 19.04 & 14.00 & 17.53 & 20.61 & 18.35 & 19.39 & 15.49 & 18.33 \\
\hline General machinery & 25.53 & 15.81 & 17.46 & 27.21 & 26.91 & 28.92 & 19.14 & 32.17 \\
\hline Electronic machinery & 26.09 & 16.40 & 15.01 & 20.43 & 23.33 & 17.49 & 13.04 & 18.70 \\
\hline Transportation machinery & 17.47 & 13.57 & 12.35 & 21.63 & 20.94 & 16.98 & 13.99 & 16.57 \\
\hline
\end{tabular}

Note: See Table 1 for a precise definition of sample firms; workers with moderate education are those who successfully completed secondary school (12 years), but not tertiary education.

Source: Author's compilations from General Statistics Office (2011, 2013). 
Table 5: Shares of workers in highly paid occupation in sample firms in 2009 (percent)

\begin{tabular}{lrrrr}
\hline Industry & Private & SOEs & WFs & JVs \\
\hline 11 sample industries & 16.30 & 23.78 & 16.04 & 22.13 \\
Food \& beverages & 16.26 & 22.45 & 24.06 & 22.12 \\
Textiles & 12.84 & 15.57 & 12.55 & 18.00 \\
Apparel, leather, \& footwear & 10.99 & 11.54 & 9.05 & 9.16 \\
Wood products \& furniture & 12.93 & 17.98 & 10.40 & 15.37 \\
Paper & 16.83 & 15.88 & 16.02 & 31.62 \\
Chemicals, rubber, \& plastics & 21.52 & 27.32 & 21.52 & 24.87 \\
Non-metallic mineral products & 14.30 & 22.31 & 18.83 & 22.23 \\
Basic metals \& metal products & 20.70 & 25.34 & 18.65 & 29.73 \\
General machinery & 25.95 & 43.86 & 21.76 & 26.57 \\
Electronic machinery & 25.50 & 33.06 & 16.95 & 27.23 \\
Transportation machinery & 20.39 & 30.51 & 18.91 & 27.20 \\
\hline
\end{tabular}

Note: See Table 1 for a precise definition of sample firms; highly paid occupations are defined as (1) managers and (2) professional, technical and supervisory employees.

Source: Author's compilations from General Statistics Office $(2011,2013)$. 
Table 6: OLS Estimates of slope ownership-related wage differentials and other slope coefficients from estimates of equation (1); all p-values based on robust standard errors; 11 sample industries combined

\begin{tabular}{|c|c|c|c|c|}
\hline \multirow[b]{2}{*}{$\begin{array}{l}\text { Independent variable, } \\
\text { indicator }\end{array}$} & \multicolumn{2}{|c|}{2009} & \multicolumn{2}{|c|}{2007} \\
\hline & Lagged & $\begin{array}{l}\text { Contem- } \\
\text { poraneous }\end{array}$ & Lagged & $\begin{array}{l}\text { Contem- } \\
\text { poraneous }\end{array}$ \\
\hline KI & 0.0106 & 0.0034 & $0.0374 \mathrm{a}$ & $0.0114 \mathrm{a}$ \\
\hline$R O$ & 0.1817 a & 0.1378 a & 0.1955 a & $0.1378 \mathrm{a}$ \\
\hline SH & $0.0091 \mathrm{a}$ & $0.0089 \mathrm{a}$ & $0.0144 \mathrm{a}$ & $0.0143 \mathrm{a}$ \\
\hline$S M$ & $0.0008 \mathrm{~b}$ & $0.0008 \mathrm{~b}$ & $0.0014 \mathrm{a}$ & 0.0014 a \\
\hline$S F$ & $-0.0036 \mathrm{a}$ & $-0.0036 \mathrm{a}$ & $-0.0036 \mathrm{a}$ & -0.0035 a \\
\hline$S P$ & $0.0035 \mathrm{a}$ & 0.0035 a & \multicolumn{2}{|c|}{ not available } \\
\hline$D W$ & $0.2553 \mathrm{a}$ & $0.2502 \mathrm{a}$ & $0.2202 \mathrm{a}$ & $0.2071 \mathrm{a}$ \\
\hline DJ & 0.2605 a & $0.2492 \mathrm{a}$ & $0.2718 \mathrm{a}$ & $0.2543 \mathrm{a}$ \\
\hline DS & $0.0974 \mathrm{a}$ & $0.0864 \mathrm{a}$ & 0.1456 a & 0.1289 a \\
\hline Test $D W=D J$ & 247.56 a & 239.95 a & $111.57 \mathrm{a}$ & $99.54 \mathrm{a}$ \\
\hline Observations & 10,698 & 10,698 & 10,221 & 10,221 \\
\hline $\mathrm{R}^{2}$ & 0.482 & 0.480 & 0.423 & 0.419 \\
\hline \#industry dummies & 28 & 28 & 28 & 28 \\
\hline
\end{tabular}

Notes: a=signficant at the $1 \%$ level, b=significant at the $5 \%$ level, c=significant at the $10 \%$ level; all estimates include 5 regional dummies and 53 industry dummies (see the text for definitions); theTestDFs rows show Wald tests of the hypothesis that coefficients on DW and DJ are equal and associated p-values; full results including the constant and all dummy coefficients are available from the authors. 
Table 7: Industry-level OLS estimates of ownership-related wage differentials from estimates of equation (1) ; all p-values based on robust standard errors

\begin{tabular}{|c|c|c|c|c|}
\hline \multirow[b]{2}{*}{ Differential, industry } & \multicolumn{2}{|c|}{2009} & \multicolumn{2}{|c|}{2007} \\
\hline & Lagged & $\begin{array}{l}\text { Contem- } \\
\text { poraneous }\end{array}$ & Lagged & $\begin{array}{l}\text { Contem- } \\
\text { poraneous }\end{array}$ \\
\hline WF-private, 11 industries & $0.2553 \mathrm{a}$ & $0.2502 \mathrm{a}$ & $0.2202 \mathrm{a}$ & $0.2071 \mathrm{a}$ \\
\hline Food \& beverages & $0.2413 \mathrm{a}$ & $0.2447 \mathrm{a}$ & $0.2102 \mathrm{a}$ & $0.1858 \mathrm{a}$ \\
\hline Textiles & $0.3358 \mathrm{a}$ & $0.3237 \mathrm{a}$ & $0.2553 \mathrm{a}$ & $0.2461 \mathrm{a}$ \\
\hline Apparel, leather, \& footwear & $0.1916 \mathrm{a}$ & $0.1872 \mathrm{a}$ & $0.1080 \mathrm{a}$ & $0.0962 \mathrm{~b}$ \\
\hline Wood products \& furniture & $0.2214 \mathrm{a}$ & 0.1923 a & 0.1450 a & $0.1207 \mathrm{a}$ \\
\hline Paper & 0.2029 a & $0.1874 \mathrm{a}$ & $0.2896 \mathrm{a}$ & $0.2764 \mathrm{a}$ \\
\hline Chemicals, rubber, \& plastics & $0.2995 \mathrm{a}$ & $0.3013 \mathrm{a}$ & $0.3206 \mathrm{a}$ & $0.3074 \mathrm{a}$ \\
\hline Non-metallic mineral products & $0.2177 \mathrm{a}$ & $0.2075 \mathrm{a}$ & 0.0972 & 0.0927 \\
\hline Basic metals \& metal products & $0.3425 \mathrm{a}$ & $0.3357 \mathrm{a}$ & $0.3155 \mathrm{a}$ & $0.3076 \mathrm{a}$ \\
\hline General machinery & $0.4390 \mathrm{a}$ & $0.4620 \mathrm{a}$ & 0.3476 a & $0.3353 \mathrm{a}$ \\
\hline Electronic machinery & $0.2170 \mathrm{a}$ & $0.2230 \mathrm{a}$ & $0.2340 \mathrm{~b}$ & $0.2418 \mathrm{~b}$ \\
\hline Transportation machinery & $0.2988 \mathrm{a}$ & $0.2758 \mathrm{a}$ & 0.4979 a & $0.4808 \mathrm{a}$ \\
\hline JV-private, 11 industries & $0.2605 \mathrm{a}$ & $0.2492 \mathrm{a}$ & $0.2718 \mathrm{a}$ & $0.2543 \mathrm{a}$ \\
\hline Food \& beverages & $0.1672 \mathrm{a}$ & $0.1687 \mathrm{a}$ & 0.2039 a & $0.1768 \mathrm{a}$ \\
\hline Textiles & $0.3599 \mathrm{~b}$ & $0.3311 \mathrm{~b}$ & $0.2260 \mathrm{~b}$ & $0.2250 \mathrm{~b}$ \\
\hline Apparel, leather, \& footwear & $0.1350 \mathrm{a}$ & $0.1229 \mathrm{~b}$ & 0.0999 & 0.0942 \\
\hline Wood products \& furniture & $0.2462 \mathrm{a}$ & $0.2232 \mathrm{a}$ & 0.1422 c & 0.1113 \\
\hline Paper & -0.8096 & -0.8791 & 0.0799 & 0.0476 \\
\hline Chemicals, rubber, \& plastics & $0.3352 \mathrm{a}$ & $0.3371 \mathrm{a}$ & 0.4785 a & $0.4688 \mathrm{a}$ \\
\hline Non-metallic mineral products & $0.2561 \mathrm{a}$ & $0.2485 \mathrm{a}$ & $0.2354 \mathrm{~b}$ & $0.2281 \mathrm{~b}$ \\
\hline Basic metals \& metal products & $0.3285 \mathrm{a}$ & $0.3162 \mathrm{a}$ & $0.4695 \mathrm{a}$ & $0.4485 \mathrm{a}$ \\
\hline General machinery & $0.3144 \mathrm{a}$ & $0.3184 \mathrm{a}$ & 0.1608 & 0.1416 \\
\hline Electronic machinery & $0.5908 \mathrm{a}$ & $0.5812 \mathrm{a}$ & $0.3721 \mathrm{~b}$ & $0.3715 \mathrm{~b}$ \\
\hline Transportation machinery & $0.3101 \mathrm{a}$ & $0.2760 \mathrm{a}$ & 0.4089 a & $0.3556 \mathrm{~b}$ \\
\hline Test WF-priv=JV-priv, 11 indus. & $247.56 \mathrm{a}$ & $239.95 \mathrm{a}$ & $111.57 \mathrm{a}$ & $99.54 \mathrm{a}$ \\
\hline Food \& beverages & $18.26 \mathrm{a}$ & 19.09 a & 8.34 a & $6.36 \mathrm{a}$ \\
\hline Textiles & $32.04 \mathrm{a}$ & 30.99 a & $12.58 \mathrm{a}$ & $11.75 \mathrm{a}$ \\
\hline Apparel, leather, \& footwear & $27.70 \mathrm{a}$ & $27.00 \mathrm{a}$ & $4.04 \mathrm{~b}$ & 3.49 \\
\hline Wood products \& furniture & 29.92 a & $22.65 \mathrm{a}$ & $9.06 \mathrm{a}$ & $6.48 \mathrm{a}$ \\
\hline Paper & $8.22 \mathrm{a}$ & $6.57 \mathrm{a}$ & 8.09 a & $7.32 \mathrm{a}$ \\
\hline Chemicals, rubber, \& plastics & $56.08 \mathrm{a}$ & $56.75 \mathrm{a}$ & $50.44 \mathrm{a}$ & $49.04 \mathrm{a}$ \\
\hline Non-metallic mineral products & $15.04 \mathrm{a}$ & 13.59 a & $3.35 \mathrm{~b}$ & $3.23 \mathrm{~b}$ \\
\hline Basic metals \& metal products & $52.71 \mathrm{a}$ & 49.35 a & 38.90 a & $36.54 \mathrm{a}$ \\
\hline General machinery & $17.52 \mathrm{a}$ & $19.25 \mathrm{a}$ & $10.72 \mathrm{a}$ & $10.20 \mathrm{a}$ \\
\hline Electronic machinery & 19.68 a & 19.53 a & $4.97 \mathrm{a}$ & $5.50 \mathrm{a}$ \\
\hline Transportation machinery & $14.45 \mathrm{a}$ & $12.57 \mathrm{a}$ & $18.44 \mathrm{a}$ & $17.42 \mathrm{a}$ \\
\hline
\end{tabular}


Table 7 (continued)

\begin{tabular}{lccccc}
\hline \multirow{2}{*}{ Differential, industry } & \multicolumn{2}{c}{2009} & & \multicolumn{2}{c}{2007} \\
\cline { 2 - 3 } \cline { 5 - 6 } & Lagged & Contem- & & Lagged & Contem- \\
\hline SOE-private, 11 industries & $0.0974 \mathrm{a}$ & $0.0864 \mathrm{a}$ & & $0.1456 \mathrm{a}$ & $0.1289 \mathrm{a}$ \\
Food \& beverages & $0.2021 \mathrm{a}$ & $0.1989 \mathrm{a}$ & & $0.2111 \mathrm{a}$ & $0.1869 \mathrm{a}$ \\
Textiles & 0.0022 & -0.0061 & & -0.0877 & -0.1119 \\
Apparel, leather, \& footwear & $0.0837 \mathrm{~b}$ & 0.0621 & & 0.0785 & 0.0534 \\
Wood products \& furniture & -0.0536 & -0.0948 & & -0.0747 & -0.0912 \\
Paper & 0.1722 & 0.1624 & & -0.0051 & -0.0675 \\
Chemicals, rubber, \& plastics & $0.2129 \mathrm{a}$ & $0.2129 \mathrm{a}$ & $0.4090 \mathrm{a}$ & $0.3941 \mathrm{a}$ \\
Non-metallic mineral products & -0.0138 & -0.0292 & & -0.0086 & -0.0183 \\
Basic metals \& metal products & 0.0755 & 0.0652 & & $0.2322 \mathrm{a}$ & $0.2088 \mathrm{a}$ \\
General machinery & 0.1126 & 0.1188 & & 0.0612 & 0.0680 \\
Electronic machinery & $0.2410 \mathrm{a}$ & $0.2337 \mathrm{a}$ & & $0.3393 \mathrm{~b}$ & $0.3509 \mathrm{~b}$ \\
Transportation machinery & 0.0278 & 0.0234 & $0.2353 \mathrm{a}$ & $0.2195 \mathrm{a}$ \\
\hline N & & &
\end{tabular}

Notes: a=signficant at the $1 \%$ level, $b=$ significant at the $5 \%$ level, $c=$ significant the 10\% level; ; see Appendix Table 3 for other slope coefficients and indicators; full results including all coefficients and equation details are available from the authors. 
Appendix Table 1: Paid employees in sample firms by ownership and industry (number)

\begin{tabular}{|c|c|c|c|c|c|c|c|c|}
\hline \multirow[b]{2}{*}{ Industry } & \multicolumn{4}{|c|}{2007} & \multicolumn{4}{|c|}{2009} \\
\hline & $\begin{array}{r}\text { Private } \\
\text { firms }\end{array}$ & SOEs & WFs & JVs & $\begin{array}{r}\text { Private } \\
\text { firms }\end{array}$ & SOEs & WFs & JVs \\
\hline 11 sample industries & $1,239,236$ & 357,645 & $1,047,385$ & 148,857 & $1,347,540$ & 310,052 & $1,320,188$ & 143,227 \\
\hline Food \& beverages & 238,522 & 49,858 & 45,254 & 20,875 & 286,290 & 38,925 & 52,697 & 25,812 \\
\hline Textiles & 61,577 & 34,213 & 49,520 & 6,921 & 62,786 & 20,829 & 55,204 & 3,195 \\
\hline Apparel, leather, \& footwear & 367,003 & 78,407 & 583,782 & 52,445 & 376,043 & 58,959 & 726,102 & 44,695 \\
\hline Wood products \& furniture & 174,483 & 20,401 & 97,545 & 8,125 & 176,407 & 12,812 & 116,657 & 7,416 \\
\hline Paper & 36,468 & 9,037 & 11,483 & 465 & 39,193 & 7,994 & 15,167 & 425 \\
\hline Chemicals, rubber, \& plastics & 82,318 & 38,724 & 55,795 & 9,220 & 94,447 & 32,824 & 77,708 & 7,205 \\
\hline Non-metallic mineral products & 129,437 & 44,624 & 12,166 & 10,829 & 151,327 & 41,263 & 13,836 & 9,528 \\
\hline Basic metals \& metal products & 76,947 & 26,924 & 37,397 & 6,345 & 82,546 & 30,426 & 53,257 & 6,401 \\
\hline General machinery & 22,173 & 7,297 & 9,309 & 614 & 23,824 & 7,888 & 11,314 & 722 \\
\hline Electronic machinery & 22,494 & 11,614 & 111,449 & 9,803 & 20,272 & 9,841 & 154,058 & 9,244 \\
\hline Transportation machinery & 27,818 & 36,548 & 33,686 & 23,218 & 34,408 & 48,293 & 44,189 & 28,586 \\
\hline Excluded industries and firms & 196,129 & 108,658 & 181,356 & 4,792 & 263,814 & 64,775 & 188,568 & 6,699 \\
\hline
\end{tabular}

Note: Firms with viable data are those with positive paid workers, output, worker compensation, and fixed assets; samples exclude firms with less than 20 employees; excluded industries are tobacco, publishing and printing, petroleum products, and recycling.

Source: Author's compilations from General Statistics Office (2011, 2013). 
Appendix Table 2: Mean compensation per worker in sample firms by ownership and industry (million dong)

\begin{tabular}{|c|c|c|c|c|c|c|c|c|}
\hline \multirow[b]{2}{*}{ Industry } & \multicolumn{4}{|c|}{2007} & \multicolumn{4}{|c|}{2009} \\
\hline & $\begin{array}{r}\text { Private } \\
\text { firms }\end{array}$ & SOEs & WFs & JVs & $\begin{array}{r}\text { Private } \\
\text { firms }\end{array}$ & SOEs & WFs & JVs \\
\hline 11 sample industries & 12.852 & 22.096 & 21.625 & 35.323 & 14.490 & 22.705 & 22.309 & 27.873 \\
\hline Food \& beverages & 11.631 & 22.294 & 18.500 & $31.050^{-}$ & 14.898 & 22.974 & 27.304 & 27.992 \\
\hline Textiles & 11.281 & 15.297 & 18.235 & 19.924 & 11.705 & 16.377 & 19.000 & 21.540 \\
\hline Apparel, leather, \& footwear & 12.124 & 12.648 & 15.031 & 15.044 & 12.533 & 14.438 & 17.482 & 16.281 \\
\hline Wood products \& furniture & 11.280 & 14.555 & 17.286 & 16.778 & 11.535 & 13.678 & 17.927 & 19.888 \\
\hline Paper & 12.554 & 19.794 & 18.364 & 28.949 & 14.420 & 23.242 & 23.230 & 13.718 \\
\hline Chemicals, rubber, \& plastics & 14.676 & 32.765 & 34.277 & 48.460 & 17.133 & 31.105 & 28.456 & 31.868 \\
\hline Non-metallic mineral products & 12.032 & 20.593 & 17.082 & 39.813 & 14.097 & 25.062 & 23.540 & 29.115 \\
\hline Basic metals \& metal products & 14.663 & 22.575 & 23.767 & 37.454 & 16.526 & 22.531 & 24.029 & 31.796 \\
\hline General machinery & 16.310 & 21.632 & 16.069 & 29.205 & 18.297 & 24.136 & 24.046 & 23.407 \\
\hline Electronic machinery & 16.087 & 30.318 & 44.431 & 46.397 & 20.106 & 30.078 & 22.396 & 43.588 \\
\hline Transportation machinery & 14.631 & 25.306 & 15.395 & 39.145 & 17.631 & 20.885 & 21.883 & 30.320 \\
\hline
\end{tabular}

Note: Firms with viable data are those with positive paid workers, output, worker compensation, and fixed assets;

samples exclude firms with less than 20 employees; excluded industries are tobacco, publishing and printing,

petroleum products, and recycling.

Source: Author's compilations from General Statistics Office (2011, 2013). 
Appendix Table 3: Sales of sample firms by ownership and industry (trillion dong)

\begin{tabular}{|c|c|c|c|c|c|c|c|c|}
\hline \multirow[b]{2}{*}{ Industry } & \multicolumn{4}{|c|}{2007} & \multicolumn{4}{|c|}{2009} \\
\hline & $\begin{array}{r}\text { Private } \\
\text { firms } \\
\end{array}$ & SOEs & WFs & JVs & $\begin{array}{r}\text { Private } \\
\text { firms } \\
\end{array}$ & SOEs & WFs & JVs \\
\hline Food \& beverages & 86,418 & 24,034 & 37,709 & 20,737 & 98,369 & 16,143 & 55,790 & 28,673 \\
\hline Textiles & 7,946 & 4,679 & 14,326 & 1,283 & 8,952 & 2,986 & 16,566 & 859 \\
\hline Apparel, leather, \& footwear & 16,110 & 6,496 & 37,311 & 4,768 & 17,271 & 4,395 & 49,026 & 3,626 \\
\hline Paper & 6,992 & 2,798 & 3,987 & 157 & 10,162 & 2,481 & 6,171 & 210 \\
\hline Chemicals, rubber, \& plastics & 25,909 & 17,336 & 21,527 & 12,373 & 31,122 & 17,201 & 35,188 & 6,019 \\
\hline Non-metallic mineral products & 15,814 & 15,287 & 3,409 & 9,115 & 18,567 & 13,129 & 3,456 & 7,933 \\
\hline Basic metals \& metal products & 29,087 & 6,218 & 13,518 & 8,460 & 43,090 & 10,697 & 16,876 & 9,593 \\
\hline General machinery & 3,746 & 1,149 & 3,500 & 188 & 4,801 & 1,425 & 4,503 & 337 \\
\hline
\end{tabular}

Note: Firms with viable data are those with positive paid workers, output, worker compensation, and fixed assets; samples

exclude firms with less than 20 employees; excluded industries are tobacco, publishing and printing, petroleum products, and recycling. 
Appendix Table 4: Number of sample firms by ownership and industry

\begin{tabular}{|c|c|c|c|c|c|c|c|c|}
\hline \multirow[b]{2}{*}{ Industry } & \multicolumn{4}{|c|}{2007} & \multicolumn{4}{|c|}{2009} \\
\hline & $\begin{array}{r}\text { Private } \\
\text { firms } \\
\end{array}$ & SOEs & WFs & JVs & $\begin{array}{r}\text { Private } \\
\text { firms } \\
\end{array}$ & SOEs & WFs & JVs \\
\hline 11 sample industries & 7,665 & 531 & 1,699 & 326 & 7,611 & 517 & 2,249 & 322 \\
\hline Food \& beverages & 1,353 & 115 & 145 & 55 & 1,337 & 104 & 164 & 59 \\
\hline Textiles & 366 & 31 & 153 & 17 & 416 & 28 & 191 & 11 \\
\hline Apparel, leather, \& footwear & 878 & 46 & 363 & 41 & 871 & 45 & 489 & 40 \\
\hline Wood products \& furniture & 1,145 & 36 & 168 & 29 & 1,245 & 28 & 224 & 32 \\
\hline Paper & 470 & 17 & 62 & 2 & 445 & 17 & 76 & 2 \\
\hline Chemicals, rubber, \& plastics & 850 & 59 & 287 & 51 & 764 & 54 & 406 & 44 \\
\hline Non-metallic mineral products & 921 & 81 & 39 & 29 & 1,062 & 78 & 59 & 30 \\
\hline Basic metals \& metal products & 1,010 & 44 & 187 & 43 & 880 & 55 & 267 & 46 \\
\hline General machinery & 242 & 19 & 51 & 6 & 196 & 19 & 63 & 7 \\
\hline Electronic machinery & 196 & 28 & 123 & 26 & 169 & 29 & 159 & 25 \\
\hline Transportation machinery & 234 & 55 & 121 & 27 & 226 & 60 & 151 & 26 \\
\hline Excluded industries & 1,767 & 278 & 545 & 43 & 3,400 & 177 & 717 & 50 \\
\hline
\end{tabular}

exclude firms with less than 20 employees; excluded industries are tobacco, publishing and printing, petroleum products, and recycling.

Source: Author's compilations from General Statistics Office (2011, 2013). 
Appendix Table 5: OLS Estimates of Ownership-Related Wage Differentials and Other Slope Coefficients; all p-values based on robust standard errors

\begin{tabular}{|c|c|c|c|c|c|c|c|c|}
\hline & \multicolumn{4}{|c|}{2009} & \multicolumn{4}{|c|}{2007} \\
\hline & \multicolumn{2}{|c|}{ Lagged } & \multicolumn{2}{|c|}{$\begin{array}{c}\text { Contem- } \\
\text { poraneous }\end{array}$} & \multicolumn{2}{|c|}{ Lagged } & \multicolumn{2}{|c|}{$\begin{array}{c}\text { Contem- } \\
\text { poraneous }\end{array}$} \\
\hline & Value & P-val. & Value & P-val. & Value & P-val. & Value & P-val. \\
\hline \multicolumn{9}{|c|}{ Food and beverages } \\
\hline KI & 0.0109 & 0.604 & 0.0296 & 0.027 & 0.0878 & 0.000 & 0.0322 & 0.009 \\
\hline$R O$ & 0.1808 & 0.000 & 0.1541 & 0.000 & 0.2064 & 0.000 & 0.1445 & 0.000 \\
\hline SH & 0.0123 & 0.000 & 0.0124 & 0.000 & 0.0181 & 0.000 & 0.0181 & 0.000 \\
\hline$S M$ & 0.0002 & 0.872 & 0.0002 & 0.870 & -0.0022 & 0.228 & -0.0021 & 0.241 \\
\hline$S F$ & -0.0019 & 0.011 & -0.0020 & 0.006 & -0.0031 & 0.000 & -0.0030 & 0.000 \\
\hline$S P$ & 0.0039 & 0.001 & 0.0039 & 0.001 & \multicolumn{4}{|c|}{ not available } \\
\hline$D W$ & 0.2413 & 0.000 & 0.2447 & 0.000 & 0.2102 & 0.002 & 0.1858 & 0.005 \\
\hline$D J$ & 0.1672 & 0.009 & 0.1687 & 0.008 & 0.2039 & 0.002 & 0.1768 & 0.009 \\
\hline$D S$ & 0.2021 & 0.000 & 0.1989 & 0.000 & 0.2111 & 0.000 & 0.1869 & 0.001 \\
\hline Test $D W=D J$ & 18.26 & 0.000 & 18.21 & 0.000 & 8.34 & 0.001 & 6.36 & 0.003 \\
\hline Obs./ $\mathrm{R}^{2}$ & 1,664 & 0.499 & 1,664 & 0.497 & 1,668 & 0.433 & 1,668 & 0.426 \\
\hline No. DI s & 3 & & 3 & & 3 & & 3 & \\
\hline \multicolumn{9}{|l|}{ Textiles } \\
\hline KI & 0.0465 & 0.130 & 0.0249 & 0.105 & 0.0461 & 0.103 & 0.0324 & 0.072 \\
\hline$R O$ & 0.1636 & 0.000 & 0.1244 & 0.000 & 0.2006 & 0.000 & 0.1128 & 0.000 \\
\hline SH & 0.0152 & 0.001 & 0.0145 & 0.001 & 0.0254 & 0.000 & 0.0255 & 0.000 \\
\hline$S M$ & -0.0007 & 0.633 & -0.0008 & 0.605 & 0.0023 & 0.373 & 0.0025 & 0.336 \\
\hline$S F$ & -0.0022 & 0.064 & -0.0023 & 0.051 & -0.0020 & 0.082 & -0.0020 & 0.079 \\
\hline$S P$ & 0.0044 & 0.026 & 0.0045 & 0.025 & \multicolumn{4}{|c|}{ not available } \\
\hline$D W$ & 0.3358 & 0.000 & 0.3237 & 0.000 & 0.2553 & 0.000 & 0.2461 & 0.000 \\
\hline$D J$ & 0.3599 & 0.013 & 0.3311 & 0.019 & 0.2260 & 0.020 & 0.2250 & 0.016 \\
\hline DS & 0.0022 & 0.976 & -0.0061 & 0.932 & -0.0877 & 0.366 & -0.1119 & 0.243 \\
\hline Test $D W=D J$ & 32.04 & 0.000 & 18.21 & 0.000 & 12.58 & 0.000 & 11.75 & 0.000 \\
\hline Obs./R ${ }^{2}$ & 646 & 0.483 & 646 & 0.480 & 567 & 0.468 & 567 & 0.460 \\
\hline No. DIs & 0 & & 0 & & 0 & & 0 & \\
\hline \multicolumn{9}{|c|}{ Apparel and leather products } \\
\hline$K I$ & 0.0050 & 0.734 & -0.0070 & 0.458 & 0.0368 & 0.063 & -0.0006 & 0.963 \\
\hline$R O$ & 0.1729 & 0.000 & 0.1179 & 0.000 & 0.1811 & 0.000 & 0.1175 & 0.000 \\
\hline SH & 0.0041 & 0.130 & 0.0042 & 0.118 & 0.0123 & 0.002 & 0.0126 & 0.002 \\
\hline$S M$ & -0.0020 & 0.206 & -0.0019 & 0.218 & -0.0015 & 0.317 & -0.0012 & 0.408 \\
\hline$S F$ & -0.0032 & 0.001 & -0.0031 & 0.001 & -0.0012 & 0.322 & -0.0012 & 0.329 \\
\hline$S P$ & 0.0039 & 0.019 & 0.0037 & 0.028 & \multicolumn{4}{|c|}{ not available } \\
\hline$D W$ & 0.1916 & 0.000 & 0.1872 & 0.000 & 0.1080 & 0.004 & 0.0962 & 0.011 \\
\hline$D J$ & 0.1350 & 0.010 & 0.1229 & 0.019 & 0.0999 & 0.162 & 0.0942 & 0.19 \\
\hline$D S$ & 0.0837 & 0.044 & 0.0621 & 0.133 & 0.0785 & 0.132 & 0.0534 & 0.3 \\
\hline Test $D W=D J$ & 27.70 & 0.000 & 18.21 & 0.000 & 4.04 & 0.049 & 3.49 & 0.104 \\
\hline Obs./R ${ }^{2}$ & 1,445 & 0.391 & 1,445 & 0.386 & 1,328 & 0.281 & 1,328 & 0.2726 \\
\hline No. DI s & 1 & & 1 & & 1 & & 0 & \\
\hline
\end{tabular}


Appendix Table 5 (continued)

\begin{tabular}{|c|c|c|c|c|c|c|c|c|}
\hline & \multicolumn{4}{|c|}{2009} & \multicolumn{4}{|c|}{2007} \\
\hline & \multicolumn{2}{|c|}{ Lagged } & \multicolumn{2}{|c|}{ Contem- } & \multicolumn{2}{|c|}{ Lagged } & \multicolumn{2}{|c|}{ Contem- } \\
\hline & Value & P-val. & Value & P-val. & Value & P-val. & Value & P-val. \\
\hline \multicolumn{9}{|c|}{ Wood products and furniture } \\
\hline KI & 0.0550 & 0.001 & 0.0192 & 0.091 & 0.0535 & 0.002 & 0.0193 & 0.086 \\
\hline$R O$ & 0.2611 & 0.000 & 0.1561 & 0.000 & 0.1916 & 0.000 & 0.1496 & 0.000 \\
\hline SH & 0.0092 & 0.003 & 0.0081 & 0.010 & 0.0121 & 0.000 & 0.0119 & 0.000 \\
\hline$S M$ & 0.0003 & 0.854 & 0.0003 & 0.827 & 0.0030 & 0.027 & 0.0030 & 0.024 \\
\hline$S F$ & -0.0053 & 0.000 & -0.0053 & 0.000 & -0.0052 & 0.000 & -0.0051 & 0.000 \\
\hline$S P$ & 0.0084 & 0.000 & 0.0089 & 0.000 & \multicolumn{4}{|c|}{ not available } \\
\hline$D W$ & 0.2214 & 0.000 & 0.1923 & 0.000 & 0.1450 & 0.000 & 0.1207 & 0.000 \\
\hline$D J$ & 0.2462 & 0.000 & 0.2232 & 0.000 & 0.1422 & 0.057 & 0.1113 & 0.130 \\
\hline DS & -0.0536 & 0.378 & -0.0948 & 0.127 & -0.0747 & 0.399 & -0.0912 & 0.297 \\
\hline Test $D W=D J$ & 29.92 & 0.000 & 18.21 & 0.000 & 9.06 & 0.000 & 6.48 & 0.000 \\
\hline Obs./R ${ }^{2}$ & 1,529 & 0.477 & 1,529 & 0.460 & 1,378 & 0.385 & 1,378 & 0.379 \\
\hline No. DIs & 1 & & 1 & & 1 & & 1 & \\
\hline \multicolumn{9}{|l|}{ Paper products } \\
\hline$K I$ & 0.0757 & 0.031 & 0.0094 & 0.642 & 0.0516 & 0.117 & 0.0123 & 0.501 \\
\hline$R O$ & 0.1201 & 0.000 & 0.1513 & 0.000 & 0.2713 & 0.000 & 0.1739 & 0.000 \\
\hline SH & 0.0080 & 0.003 & 0.0089 & 0.001 & 0.0124 & 0.000 & 0.0133 & 0.000 \\
\hline$S M$ & -0.0001 & 0.977 & 0.0004 & 0.850 & 0.0019 & 0.299 & 0.0016 & 0.339 \\
\hline$S F$ & 0.0002 & 0.888 & 0.0004 & 0.756 & -0.0015 & 0.193 & -0.0013 & 0.257 \\
\hline$S P$ & 0.0030 & 0.109 & 0.0029 & 0.116 & \multicolumn{4}{|c|}{ not available } \\
\hline$D W$ & 0.2029 & 0.000 & 0.1874 & 0.001 & 0.2896 & 0.000 & 0.2764 & 0.000 \\
\hline$D J$ & -0.8096 & 0.195 & -0.8791 & 0.202 & 0.0799 & 0.413 & 0.0476 & 0.656 \\
\hline DS & 0.1722 & 0.160 & 0.1624 & 0.191 & -0.0051 & 0.977 & -0.0675 & 0.721 \\
\hline Test $D W=D J$ & 8.22 & 0.000 & 18.21 & 0.000 & 8.09 & 0.000 & 7.32 & 0.001 \\
\hline Obs./R ${ }^{2}$ & 540 & 0.417 & 540 & 0.404 & 551 & 0.415 & 551 & 0.401 \\
\hline No. DIs & 0 & & 0 & & 0 & & 0 & \\
\hline \multicolumn{9}{|c|}{ Chemical, Rubber and Plastics } \\
\hline KI & -0.0085 & 0.617 & 0.0005 & 0.964 & 0.0355 & 0.096 & 0.0081 & 0.469 \\
\hline$R O$ & 0.1302 & 0.000 & 0.1275 & 0.000 & 0.2266 & 0.000 & 0.1362 & 0.000 \\
\hline SH & 0.0101 & 0.000 & 0.0101 & 0.000 & 0.0150 & 0.000 & 0.0145 & 0.000 \\
\hline$S M$ & 0.0017 & 0.101 & 0.0017 & 0.095 & 0.0019 & 0.066 & 0.0019 & 0.060 \\
\hline$S F$ & -0.0015 & 0.013 & -0.0015 & 0.013 & -0.0008 & 0.239 & -0.0008 & 0.279 \\
\hline$S P$ & 0.0040 & 0.000 & 0.0040 & 0.000 & \multicolumn{4}{|c|}{ not available } \\
\hline$D W$ & 0.2995 & 0.000 & 0.3013 & 0.000 & 0.3206 & 0.000 & 0.3074 & 0.000 \\
\hline$D J$ & 0.3352 & 0.000 & 0.3371 & 0.000 & 0.4785 & 0.000 & 0.4688 & 0.000 \\
\hline DS & 0.2129 & 0.001 & 0.2129 & 0.001 & 0.4090 & 0.000 & 0.3941 & 0.000 \\
\hline Test $D W=D J$ & 56.08 & 0.000 & 18.21 & 0.000 & 50.44 & 0.000 & 49.04 & 0.000 \\
\hline Obs./R ${ }^{2}$ & 1,268 & 0.528 & 1,268 & 0.528 & 1,247 & 0.513 & 1,247 & 0.506 \\
\hline No. DIs & 3 & & 3 & & 3 & & 3 & \\
\hline
\end{tabular}


Appendix Table 5 (continued)

\begin{tabular}{|c|c|c|c|c|c|c|c|c|}
\hline & \multicolumn{4}{|c|}{2009} & \multicolumn{4}{|c|}{2007} \\
\hline & \multicolumn{2}{|c|}{ Lagged } & \multicolumn{2}{|c|}{ Contem- } & \multicolumn{2}{|c|}{ Lagged } & \multicolumn{2}{|c|}{ Contem- } \\
\hline & Value & P-val. & Value & P-val. & Value & P-val. & Value & P-val. \\
\hline \multicolumn{9}{|c|}{ Non-metallic mineral products } \\
\hline KI & -0.0356 & 0.014 & -0.0247 & 0.013 & -0.0122 & 0.592 & -0.0111 & 0.408 \\
\hline$R O$ & 0.2591 & 0.000 & 0.1956 & 0.000 & 0.2441 & 0.000 & 0.1966 & 0.000 \\
\hline SH & 0.0090 & 0.000 & 0.0086 & 0.000 & 0.0114 & 0.053 & 0.0113 & 0.056 \\
\hline$S M$ & -0.0027 & 0.001 & -0.0026 & 0.002 & 0.0017 & 0.247 & 0.0017 & 0.267 \\
\hline$S F$ & -0.0027 & 0.000 & -0.0026 & 0.000 & -0.0037 & 0.000 & -0.0037 & 0.000 \\
\hline$S P$ & 0.0054 & 0.000 & 0.0058 & 0.000 & \multicolumn{4}{|c|}{ not available } \\
\hline$D W$ & 0.2177 & 0.000 & 0.2075 & 0.000 & 0.0972 & 0.263 & 0.0927 & 0.294 \\
\hline$D J$ & 0.2561 & 0.000 & 0.2485 & 0.000 & 0.2354 & 0.013 & 0.2281 & 0.014 \\
\hline DS & -0.0138 & 0.785 & -0.0292 & 0.570 & -0.0086 & 0.868 & -0.0183 & 0.726 \\
\hline Test $D W=D J$ & 15.04 & 0.000 & 18.21 & 0.000 & 3.35 & 0.036 & 3.23 & 0.040 \\
\hline Obs./R ${ }^{2}$ & 1,229 & 0.503 & 1,229 & 0.496 & 1,070 & 0.504 & 1,070 & 0.501 \\
\hline No. DIs & 1 & & 1 & & 1 & & 1 & \\
\hline \multicolumn{9}{|c|}{ Basic metals \& metal products } \\
\hline KI & 0.0240 & 0.261 & 0.0105 & 0.409 & 0.0183 & 0.283 & 0.0106 & 0.343 \\
\hline$R O$ & 0.1481 & 0.000 & 0.1154 & 0.000 & 0.1898 & 0.000 & 0.1277 & 0.000 \\
\hline SH & 0.0083 & 0.000 & 0.0081 & 0.000 & 0.0077 & 0.003 & 0.0077 & 0.003 \\
\hline$S M$ & 0.0003 & 0.682 & 0.0003 & 0.600 & 0.0012 & 0.203 & 0.0012 & 0.199 \\
\hline$S F$ & -0.0047 & 0.000 & -0.0047 & 0.000 & -0.0047 & 0.000 & -0.0047 & 0.000 \\
\hline$S P$ & 0.0010 & 0.345 & 0.0010 & 0.339 & \multicolumn{4}{|c|}{ not available } \\
\hline$D W$ & 0.3425 & 0.000 & 0.3357 & 0.000 & 0.3155 & 0.000 & 0.3076 & 0.000 \\
\hline$D J$ & 0.3285 & 0.000 & 0.3162 & 0.000 & 0.4695 & 0.000 & 0.4485 & 0.000 \\
\hline DS & 0.0755 & 0.140 & 0.0652 & 0.201 & 0.2322 & 0.000 & 0.2088 & 0.001 \\
\hline Test $D W=D J$ & 52.71 & 0.000 & 18.21 & 0.000 & 38.90 & 0.000 & 36.54 & 0.000 \\
\hline Obs./R ${ }^{2}$ & 1,248 & 0.386 & 1,248 & 0.384 & 1,284 & 0.336 & 1,284 & 0.331 \\
\hline No. DIs & 3 & & 3 & & 3 & & 3 & \\
\hline \multicolumn{9}{|c|}{ General machinery } \\
\hline$K I$ & -0.0645 & 0.303 & -0.0442 & 0.022 & 0.0535 & 0.077 & 0.0132 & 0.512 \\
\hline$R O$ & 0.0434 & 0.390 & 0.1012 & 0.000 & 0.1500 & 0.002 & 0.1491 & 0.000 \\
\hline SH & 0.0057 & 0.002 & 0.0059 & 0.001 & 0.0134 & 0.000 & 0.0133 & 0.001 \\
\hline$S M$ & 0.0028 & 0.010 & 0.0028 & 0.011 & 0.0017 & 0.138 & 0.0018 & 0.122 \\
\hline$S F$ & -0.0073 & 0.000 & -0.0075 & 0.000 & -0.0054 & 0.000 & -0.0054 & 0.000 \\
\hline$S P$ & 0.0031 & 0.043 & 0.0031 & 0.040 & \multicolumn{4}{|c|}{ not available } \\
\hline$D W$ & 0.4390 & 0.000 & 0.4620 & 0.000 & 0.3476 & 0.000 & 0.3353 & 0.000 \\
\hline$D J$ & 0.3144 & 0.010 & 0.3184 & 0.008 & 0.1608 & 0.446 & 0.1416 & 0.496 \\
\hline$D S$ & 0.1126 & 0.164 & 0.1188 & 0.140 & 0.0612 & 0.573 & 0.0680 & 0.533 \\
\hline Test $D W=D J$ & 17.52 & 0.000 & 18.21 & 0.000 & 10.72 & 0.000 & 10.20 & 0.000 \\
\hline Obs./R ${ }^{2}$ & 285 & 0.447 & 285 & 0.441 & 318 & 0.442 & 318 & 0.438 \\
\hline No. DIs & 0 & & 0 & & 0 & & 0 & \\
\hline
\end{tabular}




\begin{tabular}{|c|c|c|c|c|c|c|c|c|}
\hline & \multicolumn{4}{|c|}{2009} & \multicolumn{4}{|c|}{2007} \\
\hline & \multicolumn{2}{|c|}{ Lagged } & \multicolumn{2}{|c|}{ Contem- } & \multicolumn{2}{|c|}{ Lagged } & \multicolumn{2}{|c|}{ Contem- } \\
\hline & Value & P-val. & Value & P-val. & Value & P-val. & Value & P-val. \\
\hline \multicolumn{9}{|c|}{ Electronic machinery } \\
\hline KI & -0.0011 & 0.980 & 0.0052 & 0.799 & 0.0570 & 0.397 & 0.0441 & 0.190 \\
\hline$R O$ & 0.1213 & 0.000 & 0.0820 & 0.000 & 0.0351 & 0.385 & 0.0632 & 0.016 \\
\hline SH & 0.0083 & 0.000 & 0.0081 & 0.000 & 0.0175 & 0.000 & 0.0176 & 0.000 \\
\hline$S M$ & 0.0005 & 0.752 & 0.0005 & 0.745 & 0.0046 & 0.002 & 0.0045 & 0.003 \\
\hline$S F$ & -0.0042 & 0.001 & -0.0043 & 0.000 & -0.0030 & 0.009 & -0.0030 & 0.010 \\
\hline$S P$ & 0.0036 & 0.097 & 0.0037 & 0.090 & \multicolumn{4}{|c|}{ not available } \\
\hline$D W$ & 0.2170 & 0.000 & 0.2230 & 0.000 & 0.2340 & 0.018 & 0.2418 & 0.020 \\
\hline$D J$ & 0.5908 & 0.000 & 0.5812 & 0.000 & 0.3721 & 0.019 & 0.3715 & 0.014 \\
\hline$D S$ & 0.2410 & 0.005 & 0.2337 & 0.006 & 0.3393 & 0.016 & 0.3509 & 0.013 \\
\hline Test $D W=D J$ & 19.7 & 0.000 & 18.2 & 0.000 & 5.0 & 0.008 & 5.5 & 0.004 \\
\hline Obs./R ${ }^{2}$ & 382 & 0.437 & 382 & 0.435 & 373 & 0.347 & 373 & 0.346 \\
\hline No. DIs & 4 & & 4 & & 4 & & 4 & \\
\hline \multicolumn{9}{|c|}{ Transportation machinery } \\
\hline$K I$ & -0.0143 & 0.608 & -0.0586 & 0.000 & 0.0108 & 0.811 & -0.0412 & 0.146 \\
\hline$R O$ & 0.1471 & 0.000 & 0.1089 & 0.000 & 0.1885 & 0.000 & 0.1193 & 0.000 \\
\hline SH & 0.0050 & 0.017 & 0.0046 & 0.029 & 0.0114 & 0.004 & 0.0118 & 0.004 \\
\hline$S M$ & 0.0019 & 0.087 & 0.0020 & 0.075 & 0.0006 & 0.741 & 0.0006 & 0.755 \\
\hline$S F$ & -0.0031 & 0.008 & -0.0030 & 0.009 & -0.0053 & 0.002 & -0.0055 & 0.001 \\
\hline$S P$ & 0.0013 & 0.327 & 0.0016 & 0.221 & \multicolumn{4}{|c|}{ not available } \\
\hline$D W$ & 0.2988 & 0.000 & 0.2758 & 0.000 & 0.4979 & 0.000 & 0.4808 & 0.000 \\
\hline DJ & 0.3101 & 0.000 & 0.2760 & 0.001 & 0.4089 & 0.005 & 0.3556 & 0.012 \\
\hline$D S$ & 0.0278 & 0.619 & 0.0234 & 0.677 & 0.2353 & 0.004 & 0.2195 & 0.008 \\
\hline Test $D W=D J$ & 14.5 & 0.000 & 18.2 & 0.000 & 18.4 & 0.000 & 17.4 & 0.000 \\
\hline Obs./ $\mathrm{R}^{2}$ & 462 & 0.431 & 462 & 0.424 & 437 & 0.376 & 437 & 0.368 \\
\hline No. DIs & 1 & & 1 & & 1 & & 1 & \\
\hline
\end{tabular}

Note: in the Obs./R2 rows, the coefficient column contains the number of observations and the Pvalue column contains the R-squared; all estimates include 5 regional dummies; see the text for definitions or region and industry dummies; the Test DFs rows show Wald tests of the hypothesis that coefficients on DW and DJ are equal and associated p-values; and full results including the constant and all dummy coefficients are available from the authors. 
Appendix Table 6: VSIC Categories included in each industry group

\begin{tabular}{ll}
\hline Industry name & VSIC Categories included \\
\hline Manufacturing & Sum or Mean of 11 sample industries and excluded industries below \\
11 sample industries & Sum or Mean of 11 sample industries below \\
Food \& beverages & VSIC 15 \\
Textiles & VSIC 17 \\
Apparel, leather, \& footwear & VSIC 18 \& 19 \\
Wood products \& furniture & VSIC 20 \& 361 \\
Paper, printing, \& publishing & VSIC 21 \\
Chemicals, rubber, \& plastics & VSIC 24 \& 25 \\
Non-metallic mineral products & VSIC 26 \\
Basic metals \& metal products & VSIC 27 \& 28 \\
General machinery & VSIC 29 \\
Electronic machinery & VSIC 30,31,32 \&33 \\
Transportation machinery & VSIC 34 \& 35 \\
Excluded industries & VSIC 16, 22, 23, 369 \& 37 \\
\hline
\end{tabular}


Applendix Table 7: Nominal minimum wages per month in Vietnam, 2000-2010 (thousand dong)

\begin{tabular}{|c|c|c|c|c|c|c|c|c|}
\hline Year & 2000-01 & 2002 & 2003-04 & 2005 & 2006-07 & 2008 & 2009 & 2010 \\
\hline \multicolumn{9}{|c|}{ Domestic firms } \\
\hline Region 1 & \multirow{4}{*}{180} & & \multirow{4}{*}{290} & \multirow{4}{*}{350} & \multirow{4}{*}{450} & 620 & 800 & 980 \\
\hline Region 2 & & 210 & & & & 580 & 740 & 880 \\
\hline Region 3 & & 210 & & & & 540 & 690 & 810 \\
\hline Region 4 & & & & & & 540 & 650 & 730 \\
\hline MNEs & & & 2005 & & 2006-07 & 2008 & 2009 & 2010 \\
\hline Region 1 & & & & & 870 & 1000 & 1200 & 1,340 \\
\hline Region 2 & & & & & 790 & 900 & 1080 & 1,190 \\
\hline Region 3 & & & & & 710 & 800 & 950 & 1,040 \\
\hline Region 4 & & & & & 710 & 800 & 920 & 1,000 \\
\hline
\end{tabular}

Notes:

(1) Minimum wage rates were uniform for all domestic firms regardless of firm location in 2000-07.

(2) Region-specipfic, minimum wage rates did not change for MNEs in 2000-05.

(3) Regions are defined as follows:

Region 1 : Hanoi and Ho Chi Minh City.

Region 2 : Hai Phong, Dong Nai, Binh Duong, Ba Ria Vung Tau, Quang Ninh, Da Nang, and Can

Region 3 : Other provinces.

Region 4 : Bac Kan, Binh Phuoc, Dak Nong, Lai Chau, and Tay Ninh.

Sources: Vietnamese government degrees compiled by Nguyen (2014, p. 52). 